\title{
A SYSTEMATIC REVIEW OF INFORMATION MODELLING OF INDIVIDUAL RESIDENTIAL BUILDINGS
}

\author{
Darius KALIBATAS ${ }^{1}$, Diana KALIBATIENE ${ }^{2}$, Oleg KAPLIŃSKI ${ }^{3 *}$ \\ ${ }^{1}$ Faculty of Civil Engineering, Vilnius Gediminas Technical University, \\ Sauletekio al. 11, LT-10233 Vilnius, Lithuania \\ ${ }^{2}$ Faculty of Fundamental Sciences, Vilnius Gediminas Technical University, \\ Sauletekio al. 11, LT-10233 Vilnius, Lithuania \\ ${ }^{3}$ Faculty of Architecture, Poznań University of Technology, Nieszawska Str. 13, 60-965 Poznań, Poland
}

Received 5 May 2018; accepted 21 June 2018

\begin{abstract}
Rapidly growing building information modelling (BIM) in construction offers a number of advantages and new opportunities of improving efficiency and effectiveness of the construction process and enhancing the use of emerging technology throughout the project's lifecycle, not only in new buildings, but also in existing ones, including overall infrastructure. Recently, there has been a great number of publications discussing BIM advantages in construction. A number of review papers summarising BIM usage cases have been published. However, as the preliminary research shows, not all organizations use BIM because of its disadvantages. Therefore, the main aim of this research is to study the extent of available literature on BIM, to determine the current situation of BIM usage, and summarise publications related to the application of BIM. The current study is limited solely to papers available in SpringerLink, ScienceDirect and Thomson Reuters Web of Sciences scientific databases. The obtained results make it clear that BIM case studies and research in academic journals show high level of BIM implementation in practice, and advantages of BIM. However, there are some limitations of BIM usage in practice. Moreover, new trends in the evolving BIM are presented and discussed in this paper.
\end{abstract}

Keywords: BIM, building information model, construction, literature review.

\section{Introduction}

Building information modelling (BIM) is one of the most promising recent developments in the architecture, engineering, and construction (AEC) industry (Azhar, 2011). With BIM technology, an accurate virtual model of a building, called a building information model, is digitally constructed. It can be used for planning, design, actual construction, and operation of the facility. It helps architects, engineers, and constructors visualize what is to be built in a simulated environment to identify any potential design, construction, or operational issues (Azhar, 2011).

However, as the preliminary research shows, there is a number of disadvantages interfering with the usage and popularising BIM in the industry. Therefore, the main aim of this research is to study the extent of available literature on BIM, and clarify why some companies choose this technology while others do not. Consequently, this research presents a systematic review of literature in SpringerLink, ScienceDirect and Thomson Reuters Web of Sciences scientific databases.
The paper is organized as follows. Section 1 briefly introduces the concept of BIM used in related works. Section 2 describes methodology of the review. Section 3 describes the results of the review, and Section 4 presents a discussion. Finally, last Section concludes the review.

\section{Related works}

In this section, the concept of building information modelling (BIM) is briefly introduced, and the overview some important publications is presented.

As recently proposed by (Wang \& Song, 2016), BIM is becoming increasingly popular in the Architecture, Engineering and Construction (AEC) industry. Many researchers and practitioners have verified the benefits of BIM as compared to traditional information technologies, such as Autodesk CAD. According to the authors (Wang \& Song, 2016; Aranda-Mena, Crawford, Chevez, \& Froese, 2009) BIM incorporates software, information of a process

${ }^{*}$ Corresponding author. E-mail: oleg.kaplinski@put.poznan.pl 
for designing and documenting a building, new policies, standards and regulations, etc. According to the United States (U.S.) National BIM standard, BIM is defined as "a digital representation of physical and functional characteristics of a facility", which serves as "a shared knowledge resource for information about a facility forming a reliable basis for decisions during its life-cycle; defined as existing from earliest conception to demolition".

There is a number of papers presenting BIM's origins, its history and future trends. This paper summarizes future trends presented in other publications.

Turk (2016) defines three main categories or directions of BIM development. They are as follows: BIM structure, which defines parts, their organization and how the parts work together; BIM functionality, which describes how it can be made useful; and BIM behaviour, which describes how it responds to its environment. The author defines future BIM trends in the scope of these three categories. However, they are very broad. The more detailed BIM directions (in whole 12) are presented in (Merschbrock \& Munkvold, 2012) and adapted from (Isikdag \& Underwood, 2010).

Anumba (2016) defines BIM's emerging directions as well. However, they are mainly related to information technology (IT). Authors (Jung \& Joo, 2011) present a detailed BIM practical implementation framework, which can be used as such and for analysis of future trends. Their analysed framework consists of three main directions, namely construction business function, BIM perspective and BIM technology. After the analysis, the authors stated that knowledge (in within the property level variable) and reasoning (within the ontology variable) are promising areas for advanced BIM, and cost-effective approaches, using structured BIM properties, found in literature and in actual industry experience.

Saoud, Omran, Hassan, Vilutiené, and Kiaulakis (2017) describe the developed method to predict the propagation of change through BIM, and provide the concept of visual technology to help designers to predict the change in the construction industry. The developed method includes the use of parameter-based Design Structure Matrix (DSM) as a tool for predicting change propagation. Their case study demonstrates the possibilities of the method in BIM environment. Matthews et al. (2015), Matthews, Love, Mew- burn, Stobaus, and Ramanayaka (2018) also analyse real time progress management and a change in management perspectives.

Also a number of papers present different applications of BIM, like in (Liao \& Teo, 2017) the authors identify 15 success factors of applying BIM, in (Ustinovichius, Peckiene, \& Popov, 2017) the authors have used BIM for spatial planning of the site, in (Juan, Lai, \& Shih, 2017), investigated the current status of BIM adoption in 224 Taiwanese architectural firms and created a predictive model that can be used by decision makers who are considering adopting BIM. The results revealed that approximately one third of the firms surveyed had already adopted BIM-based tools (Juan et al., 2017). More than half of the firms were willing to use BIM-based tools to streamline the building permit review process; however, their willingness was strongly influenced by governmental policies, competitor motivation, financial incentives, and technological support.

The next section presents the methodology of a systematic literature review on BIM.

\section{Methodology}

In this section, literature review process is presented. The research begins with a brief literature review of published papers on BIM in the selected databases and search engines. A well-structured and solid literature review enables researchers to identify under-researched topics and research gaps (Merschbrock \& Munkvold, 2012).

The review process is presented in Figure 1, and is based on (Pautasso, 2013).

1. Define research questions. In this step, brief research questions were defined, pertinent to the papers about BIM. They are as follows:

The review in this study can be considered a scoping study (Merschbrock \& Munkvold, 2012; Arksey \& O'Malley, 2005) and designed to cover the extent of available literature, allowing for the identification of journal articles and other publications across several research disciplines. Some possible previous studies focused on journal articles or conference proceedings originating within the construction informatics (CI) field are presented in (Amor, Betts, Coetzee, \& Sexton, 2002; Björk, 1999).

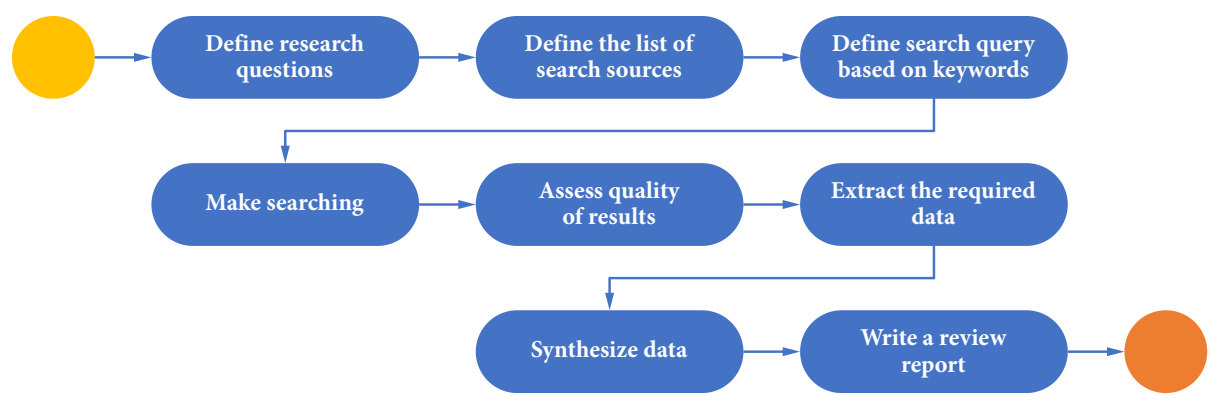

Figure 1. A systematic literature review process 
2. Define the list of search sources. In this step, the list of search sources was defined. In order to review a certain amount of papers on BIM, several digital databases and search engines naming sources were chosen. Due to the technical limitations, only free access $^{1}$ and limited number of sources were chosen. Therefore, only three sources were used (see Table 1). However, the initial study of sources shows that they contain significant number of books, journals, peer-reviewed conferences and workshops relevant to the research field.

Table 1. List of sources

\begin{tabular}{|l|l|}
\hline \multicolumn{1}{|c|}{ Data source } & \multicolumn{1}{c|}{ Website } \\
\hline SpringerLink & http://link.springer.com/ \\
\hline ScienceDirect & http://www.sciencedirect.com/ \\
\hline $\begin{array}{l}\text { Thomson Reuters Web } \\
\text { of Science }\end{array}$ & https://apps.webofknowledge.com/ \\
\hline
\end{tabular}

3. Define search query based on keywords. In this step, synonyms, related terms and their meaningful combinations are defined. The following search query has been defined:

((“BIM”) OR (“Building Information Modelling”) OR ("BIM technology") OR ("Building Information Model”)) AND ("construction" OR "building”)

Note that other terms, like "digital model", "3D modelling", etc., can also be used in the search. However, adding such terms increases the number of results, but doe not make it more specific. Therefore, they were excluded from the search.

4. Make searching. In this step, the searching process is performed according to the defined terms in step 4.

5. Assess quality of results. In this step, quality of results is assessed. According to (Kitchenham, Mendes, \& Travassos, 2007) there is no commonly agreed definition of study "quality". Therefore, quality issues presented in (Zhang, Kitchenham, \& Pfahl, 2008) were the basis for consideration.
6. Extract the required data. In this step, a required data is extracted according to the research questions, presented in step 1 .

7. Write a review report. In this step, review report is written and discussion is conducted.

\section{Results of the review}

In this section, results of our literature review are presented. Table 2 shows a summarized results of our literature review, where it is clear that, in three databases, found 8511 different publications wee found. Below, in this section, according to the searching possibilities of databases, more detailed analysis of the results will be presented.

Table 2. Summarized results of literature review in SpringerLink, Thomson Reuters Web of Science and ScienceDirect databases

\begin{tabular}{|c|c|c|c|c|}
\hline & \multicolumn{3}{|c|}{ Databases (search conducted 2016-12-01) } & \\
\hline $\begin{array}{c}\text { Year of } \\
\text { publication }\end{array}$ & SpringerLink & $\begin{array}{c}\text { Thomson } \\
\text { Reuters Web } \\
\text { of Science }\end{array}$ & $\begin{array}{c}\text { ScienceDirect } \\
\text { (including } \\
\text { Elsevier) }\end{array}$ & \\
\hline $2010-2017$ & 171 & 1754 & 1986 & \\
\hline $2000-2009$ & 768 & 156 & 409 & \\
\hline $1990-1999$ & 507 & 3 & 349 & \\
\hline$<1990$ & 489 & 0 & 374 & \\
\hline Total: & 3480 & 1913 & 3118 & 8511 \\
\hline
\end{tabular}

\subsection{SpringerLink}

In Table 3, an extended version of our literature review in SpringerLink is presented. Each column represents number of publications according to a specific attribute. For the purpose of detailed analysis, the most popular attributes available in the SpringerLink database have been chosen. Note that the original names of attributes have been left in Table 3. Moreover, the searching query, presented in Section 2.1 Step 4, was refined according to the search engine used in SpringerLink as follows:

"building information model" OR (BIM) AND (constuction OR building)

Table 3. Extended results of a literature review in SpringerLink

\begin{tabular}{|c|c|c|c|c|c|c|c|c|c|c|}
\hline \multirow[b]{2}{*}{ Year of publication } & \multicolumn{5}{|c|}{ Content type } & \multicolumn{3}{|c|}{ Discipline } & \multicolumn{2}{|c|}{ Language } \\
\hline & 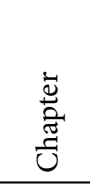 & 岂 & 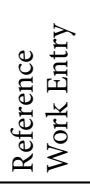 & $\begin{array}{l}\overrightarrow{0} \\
0 \\
0 \\
0 \\
0\end{array}$ & $\begin{array}{l}\text { 능 } \\
\circ \\
\infty\end{array}$ & 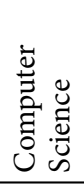 & 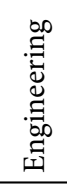 & 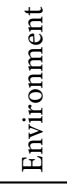 & 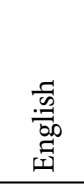 & Ẽ \\
\hline 2010-2017 & 1075 & 576 & 47 & 13 & 5 & 683 & 551 & 168 & 1570 & 144 \\
\hline 2000-2009 & 487 & 269 & 8 & 4 & 0 & 230 & 144 & 26 & 718 & 50 \\
\hline 1990-1999 & 385 & 122 & 0 & 0 & 0 & 162 & 57 & 15 & 494 & 13 \\
\hline$<1990$ & 320 & 169 & 0 & 0 & 0 & 51 & 75 & 11 & 405 & 61 \\
\hline
\end{tabular}

\footnotetext{
${ }^{1}$ VGTU has access to Thomson Reuters Web of Science.
} 
Note that in Table 3 attributes the values of which are less than 10 are not presented (relevant for other languages).

As can be seen in Table 3, the most popular content types are chapters (or proceeding papers) and articles (or journals). The most popular research areas are Computer Science, Engineering, and Environment. The most popular language is English.

\subsection{Thomson Reuters Web of Science}

In Table 4, an extended version of our literature review in Thomson Reuters Web of Science is presented. Each column represents number of publications according to a specific attribute. For the purpose of detailed analysis, the most popular attributes available in the Thomson Reuters Web of Science database were chosen. Note that the original names of attributes have been left in Table 4 . Moreover, the searching query presented in Section 2.1 Step 4 was refined according to the search engine used in Thomson Reuters Web of Science as follows:

TOPIC: ("building information model") OR TOPIC: (BIM) AND TOPIC: (construction OR building)

As can be seen in Table 4, the most popular document types are proceeding papers and journals. The most popular research areas are Engineering, Construction Building Technology and Computer Science. The most popular language is English. However, other languages are also used in publications.

A distribution of publications according to five most popular journals during 2016-2000 are presented in Ta- ble 5. Previous years (before 2000) are not analysed in details because of BIM origination.

As can be seen from Table 5, Elsevier publishes the most popular and significant journals on the topic of BIM.

\subsection{ScienceDirect}

Table 6 presents an extended version of our literature review in ScienceDirect. Each column represents a number of publications according to a specific attribute. For the detailed analysis, the most popular attributes available in the ScienceDirect database were chosen. Note that in Table 6 the original names of attributes have been left. Moreover, the searching query presented in Section 2.1 Step 4 was refined according to the search engine used in ScienceDirect as follows:

((building information model) OR BIM) AND (construction OR building)

Moreover, refined search results according to research are presented in Table 6 . The following research areas were chosen: Business, Management and Accounting; Computer Science; Decision Sciences; Design; Economics, Econometrics and Finance; Energy; Engineering; Environmental Science; and Social Sciences. Areas covering Art, Agriculture, Medicine, and Philosophy were excluded from the search.

A distribution of publications according to five most popular journals during 2016-2000 are presented in Table 7 . Years before 2000 have not been analysed because of BIM origination.

Table 4. Extended results of a literature review in Thomson Reuters Web of Science

\begin{tabular}{|c|c|c|c|c|c|c|c|c|c|c|c|c|c|c|c|c|}
\hline \multirow[b]{2}{*}{$\begin{array}{c}\text { Year of } \\
\text { publication }\end{array}$} & \multicolumn{5}{|c|}{ Document type } & \multicolumn{6}{|c|}{ Research Area } & \multicolumn{5}{|c|}{ Language } \\
\hline & 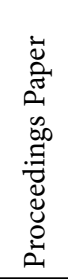 & 竞 & $\frac{3}{2}$ & 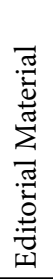 & 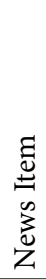 & 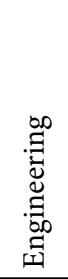 & 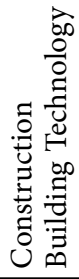 & 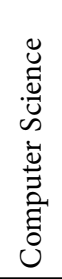 & 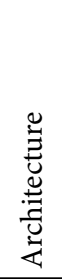 & 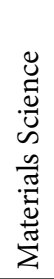 & 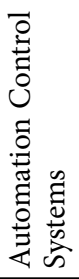 & 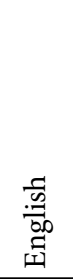 & 胥 & 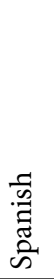 & 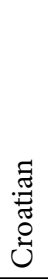 & 采 \\
\hline 2010-2017 & 920 & 787 & 31 & 20 & 4 & 962 & 581 & 484 & 173 & 79 & 27 & 1721 & 19 & 5 & 3 & 2 \\
\hline 2000-2009 & 105 & 54 & 2 & 1 & 2 & 74 & 76 & 42 & 26 & 7 & 6 & 154 & 1 & 0 & 0 & 0 \\
\hline 1990-1999 & 1 & 2 & 0 & 0 & 0 & 0 & 0 & 1 & 1 & 0 & 1 & 2 & 0 & 0 & 0 & 0 \\
\hline
\end{tabular}

Table 5. A distribution of publications according to journals in Thomson Reuters Web of Science

\begin{tabular}{|c|c|c|c|c|c|c|c|}
\hline \multirow{2}{*}{$\begin{array}{c}\text { Year of } \\
\text { publication }\end{array}$} & $\begin{array}{c}\text { Automation in } \\
\text { Construction } \\
\text { (Elsevier) }\end{array}$ & $\begin{array}{c}\text { Procedia } \\
\text { Engineering } \\
\text { (Elsevier) }\end{array}$ & $\begin{array}{c}\text { Applied } \\
\text { Mechanics and } \\
\text { Materials }\end{array}$ & $\begin{array}{c}\text { Advanced } \\
\text { Engineering } \\
\text { Informatics } \\
\text { (Elsevier) }\end{array}$ & $\begin{array}{c}\text { Journal of } \\
\text { Computing } \\
\text { in Civil } \\
\text { Engineering }\end{array}$ & $\begin{array}{c}\text { Energy and } \\
\text { Buildings } \\
\text { (Elsevier) }\end{array}$ & $\begin{array}{c}\text { Building and } \\
\text { Environment } \\
\text { (Elsevier) }\end{array}$ \\
\hline $2010-2017$ & 208 & 81 & 80 & 51 & 50 & 15 & 8 \\
\hline $2000-2009$ & 11 & 0 & 0 & 4 & 2 & 0 & 0 \\
\hline
\end{tabular}


Table 6. Extended results of ++--+ literature review in ScienceDirect

\begin{tabular}{|c|c|c|c|}
\hline \multirow{2}{*}{$\begin{array}{c}\text { Year of } \\
\text { publication }\end{array}$} & \multicolumn{3}{|c|}{ Content type } \\
\cline { 2 - 4 } & Journal & Reference Work & Book \\
\hline $2010-2017$ & 1878 & 10 & 105 \\
\hline $2000-2009$ & 356 & 6 & 61 \\
\hline $1990-1999$ & 315 & 0 & 44 \\
\hline$<1990$ & 339 & 0 & 50 \\
\hline
\end{tabular}

As can be seen in Table 7, Elsevier publishes the most popular and significant journals on the topic of BIM.

\subsection{Related papers on BIM studies}

Based on the search results, it was concluded that systematic literature reviews on BIM are now popular. Therefore, in this section several papers on BIM literature review are presented and discussed.

For the study, reviews on BIM in the period of 20082016 were chosen. The search in ScienceDirect of reviews on the topic of BIM in construction results in more than 1864 journals. From those journals, the most appropriate and recent to data have been chosen. A brief review of 9 studies is presented below.

Merschbrock \& Munkvold (2012) published their review paper on BIM in "Communications of the Association for Information Systems" in 2012. Their review process was performed in 2011-2012, and they found 1227 articles in keeping with their defined keywords in Elsevier SciVerse Scopus. Their review can be characterized as a scoping study (Arksey \& O'Malley, 2005), seeking to examine the extent, range and nature of the research activity on threedimensional BIM topics. The authors have chosen 264 papers for the detailed study and have identified that the interest in the BIM topic had risen almost exponentially from 1996-2010. Authors of (Merschbrock \& Munkvold, 2012) in their publication have identified the leading main five journals publishing BIM articles. Moreover, they explored that the bigger amount of publications proposing how to extend BIM by IT to achieve users' goals. Finally, authors of (Merschbrock \& Munkvold, 2012) have found that the main topics concerned BIM and IT are working in groups and facilitating the impact of BIM on organizations. Other publications had analysed an influence of BIM on organizations culture (Anumba, Dainty, Ison, \& Sergeant, 2006; Gal, Lyytinen, \& Yoo, 2008), production process (Arayici et al., 2011; Sacks, Treckmann, \& Rozenfeld, 2009) and measuring business value of BIM (Delone \& McLean, 2003; Melville, Kraemer, \& Gurbaxani, 2004).

Yan and Damian (2008) in their paper have presented BIM benefits and limitations. Therefore, they reviewed a historical evolution of design tools. Then, they have questioned about 70 AEC professionals how they use BIM, and what are BIM benefits and limitations. Finally, authors have found that USA is the leading country in BIM usage. However, a large number of companies are not currently using BIM, and are not going to use BIM in the future. So, authors have concluded that the BIM technology should be improved in the future to rich an appropriate maturity level.

Authors of (Volk, Stengel, \& Schultmann, 2014) reviewed more than 180 publications on BIM implementation. Results showed that nerveless BIM topic becomes more and more popular per years (2002-2012). Nerveless, BIM is not used in the existing buildings because of high efforts necessary 1) to convert existing buildings data into semantic BIM objects, 2) to update existing information in BIM, and 3) to handle inaccurate data, objects and relations occurring in existing buildings. Therefore, ways of process automation and BIM adaptation to existing buildings should be developed in the future.

In (Soust-Verdaguer, Llatas, \& García-Martínez, 2016a) authors analysed 20 case studies according to ISO 14040, ISO 14044, EN 15978, and EN 15804 standards. The main result obtained in the paper is that authors develop recommendations to develop simplification strategies that allowing us to compare single-family houses in Life Cycle Assessment (LCA).

Shou, Wang, J., Wang, X., and Chong (2015) have reviewed 40 case studies in academic journals and conference proceedings and 24 case studies in industrial reports on BIM implementation and use in AEC industry. The obtained results showed that BIM case studies in academic publications show a high level of BIM implementation in practice. As well, the analysis of BIM in infrastructure and building cases shows the BIM usage together with traditional project management.

Cerovsek (2011) provides a review of issues for BIM tools and standards, and showed the necessity for the BIM research methodology.

In (Soust-Verdaguer, Llatas, \& García-Martínez, 2016b) the authors reviewed recent studies centred on BIM-based LCA, and found the necessity to simplify BIM

Table 7. A distribution of publications according to journals in ScienceDirect

\begin{tabular}{|c|c|c|c|c|c|}
\hline \multirow{2}{*}{$\begin{array}{c}\text { Year of } \\
\text { publication }\end{array}$} & \multicolumn{5}{|c|}{ Journal title (Publisher) } \\
\cline { 2 - 6 } & $\begin{array}{c}\text { Automation in } \\
\text { Construction } \\
\text { (Elsevier) }\end{array}$ & $\begin{array}{c}\text { Procedia } \\
\text { Engineering } \\
\text { (Elsevier) }\end{array}$ & $\begin{array}{c}\text { Advanced Engineering } \\
\text { Informatics (Elsevier) }\end{array}$ & $\begin{array}{c}\text { Energy and Buildings } \\
\text { (Elsevier) }\end{array}$ & $\begin{array}{c}\text { Building and Environment } \\
\text { (Elsevier) }\end{array}$ \\
\hline $2010-2017$ & 423 & 157 & 110 & 78 & 44 \\
\hline $2000-2009$ & 40 & 0 & 16 & 3 & 3 \\
\hline
\end{tabular}


application, especially data acquisition. Finally, the authors propose recommendations for BIM and LCA tools.

Chen, Lu, Peng, Rowlinson, and Huang (2015), basing on the review of 75 papers, have proposed a conceptual framework for synchronizing information flows between BIM and real-life building processes. The authors have applied their framework to the prefabricated housing construction in Hong Kong. Moreover, as the authors have stated, their proposed framework needs information and management theories, and further exploration of practical uses of the proposed framework.

Eleftheriadis, Mumovic, and Greening (2017) reviewed BIM usage capabilities for energy efficiency in building structures. Migilinskas, Popov, Juocevicius, and Ustinovichius (2013) have analysed benefits and limitations of BIM practical implementation and found that those are fast growing technologies requiring implementation of standards and learning.

\section{Discussing the review results}

As presented in the first part of review, the scale of research on BIM has been increasing significantly. As pre- sented in Figure 2, number of journal publications grows significantly. Authors analyse BIM in different topics. The main disciplines or areas are Computer Sciences, Engineering and Construction Building Technologies (Figure 3). Therefore, it can be concluded that the topic of BIM is familiar to researchers in other fields, especially Computer Sciences. In addition, Merschbrock \& Munkvold (2012) have found that contributions in Computer Sciences would bring the knowledge further to BIM in construction.

As can be seen in Figure 4, the main journals publishing articles on BIM focus on construction and computer science. However, those journals are slightly different because publishers are included into databases. Moreover, as illustrated in Figure 4, the leading journal publishing BIM articles has not changed (Automation in Construction (Elsevier)). Other popular areas where BIM articles have been published are: architecture, environment, chemistry, etc. (see Table 3 and Table 4).

Another important finding of the research is the distribution of BIM publications according to application areas. The following detailed classification of BIM application areas in journals is presented in Table 8.

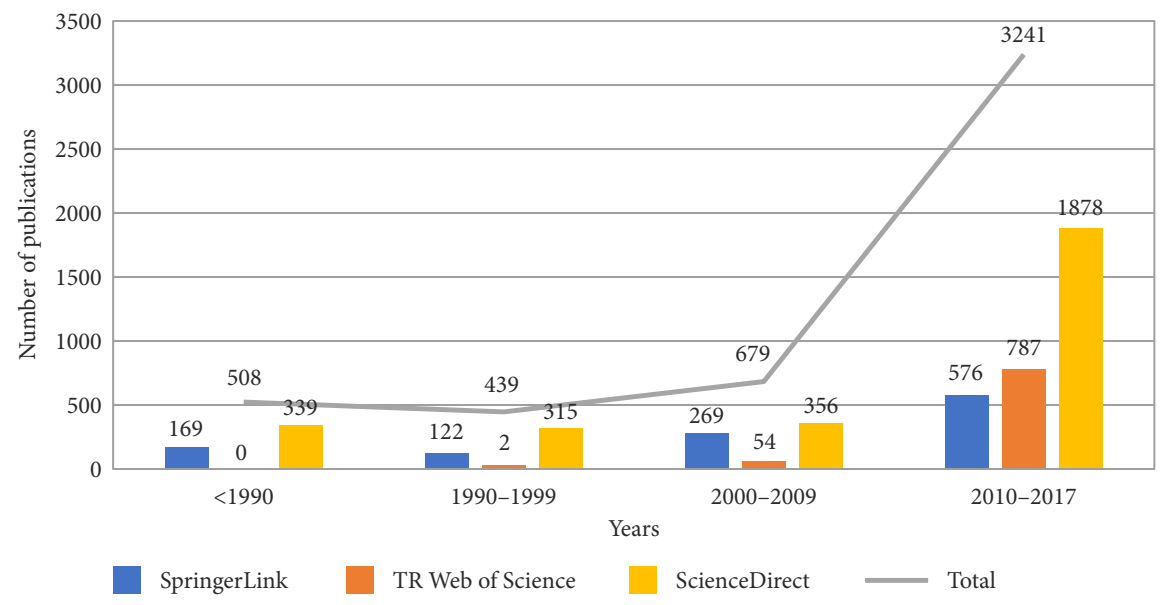

Figure 2. Number of journal publications in SpringerLink, Thomson Reuters (TR) Web of Science and ScienceDirect

TR Web of Science (2010-2016)

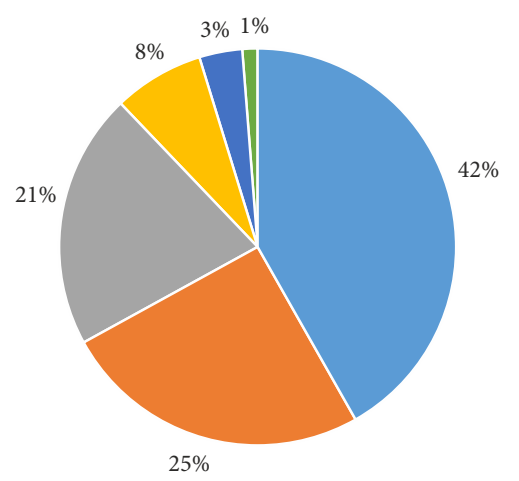

SpringerLink (2010-2016)

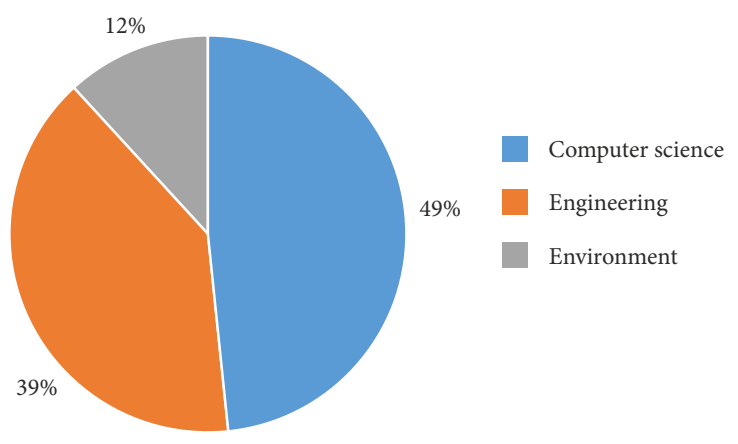

Figure 3. Distribution of publications according to the research area in SpringerLink and Thomson Reuters (TR) Web of Science at 2010-2016 
ScienceDirect (2000-2016)

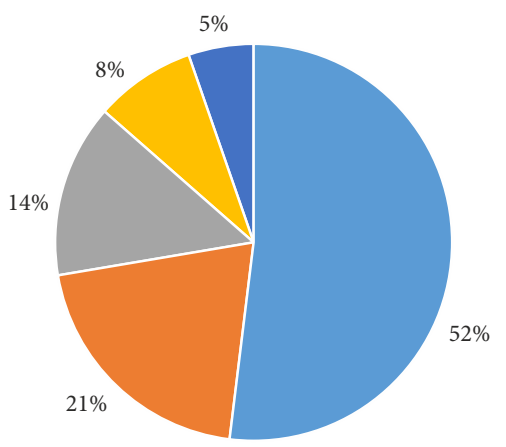

TR Web of Science (2000-2016)

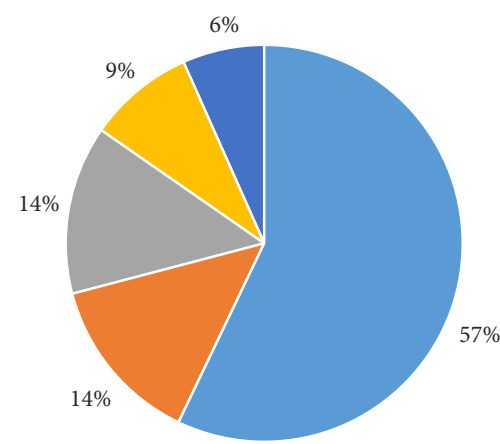

Automation in Construction (Elsevier)

Journal of Computing in Civil Engineering (ASCE)

Advanced Engineering Informatics (Elsevier)

Journal of Information Technology in Construction (CIB)

Figure 4. The leading journals publishing BIM articles

Table 8. Distribution of publications according to BIM application areas in journals

\begin{tabular}{|c|c|c|}
\hline $\begin{array}{l}\text { BIM } \\
\text { application } \\
\text { areas }\end{array}$ & Sub area & Resource \\
\hline \multirow{5}{*}{$\begin{array}{l}\text { 1. Buildings } \\
\text { analysed }\end{array}$} & 1.1. For new buildings & \\
\hline & $\begin{array}{l}\text { 1.2. For improvement of old buildings, } \\
\text { like historical buildings }\end{array}$ & (Biagini, Capone, Donato, \& Facchini, 2016) \\
\hline & $\begin{array}{l}\text { 1.3. For improvement and/or operation } \\
\text { of old buildings, like existing } \\
\text { buildings }\end{array}$ & (Volk et al., 2014; McArthur, 2015; Khaddaj \& Srour, 2016) \\
\hline & $\begin{array}{l}\text { 1.4. Case studies and Application of } \\
\text { BIM }\end{array}$ & $\begin{array}{l}\text { In Norway (Merschbrock \& Munkvold, 2015), China (Cao et al., 2015), } \\
\text { Austria (Gourlis \& Kovacic, 2016), Australia (Atazadeh, Kalantari, } \\
\text { Rajabifard, \& Ho, 2017), England (Alwan, Jones, \& Holgate, 2017), South } \\
\text { Korea (Won, Cheng, \& Lee, 2016), Iran (Shad, Khorrami, \& Ghaemi, 2017) }\end{array}$ \\
\hline & 1.5. Cost estimation & $\begin{array}{l}\text { (Ma \& Liu, 2014; Lee, Kim, \& Yu, 2014; Wang et al., 2016; Kim, Anderson, } \\
\text { Lee, \& Hildreth, 2013) }\end{array}$ \\
\hline \multirow{4}{*}{$\begin{array}{l}\text { 2. Part of the } \\
\text { building }\end{array}$} & $\begin{array}{l}\text { 2.1. Energy consumption, energy } \\
\text { saving or energy performance }\end{array}$ & $\begin{array}{l}\text { (Borgstein, Lamberts, \& Hensen, 2016; Guo \& Wei, 2016; Shadram, } \\
\text { Johansson, Lu, Schade, \& Olofsson, 2016; Ahn, Kim, Y. J., Park, Kim, I., } \\
\text { \& Lee, 2014; Azzouz, Borchers, Moreira, \& Mavrogianni, 2017; Ham \& } \\
\text { Golparvar-Fard, 2015; Di, 2015; Abanda \& Byers, 2016; Gourlis \& Kovacic, } \\
\text { 2016; Kuo, Hsieh, Guo, \& Cha, 2016; Jia, Srinivasan, \& Raheem, 2017) }\end{array}$ \\
\hline & 2.2. Daylighting analysis & (Kota, Haberl, Clayton, \& Yan, 2014) \\
\hline & 2.3. Sustainability performance & (Kreiner, Passer, \& Wallbaum, 2015) \\
\hline & 2.4. Waste management & (Lu, Webster, Chen, K., Zhang, \& Chen, X., 2017) \\
\hline \multirow{8}{*}{$\begin{array}{l}\text { 3. Computer } \\
\text { sciences }\end{array}$} & 3.1. Process optimisation & $\begin{array}{l}\text { (Ciribini, Ventura, \& Paneroni, 2016; Matthews et al., 2015; Choi, Kim, } \\
\text { H., \& Kim, I., 2015; Liu, Meng, \& Tam, 2015; Nath, Attarzadeh, Tiong, } \\
\text { Chidambaram, \& Yu, 2015) }\end{array}$ \\
\hline & 3.2. Automation, simulation & $\begin{array}{l}\text { (Kumar \& Cheng, 2015; Gao et al., 2015; Hongling, Yantao, Weisheng, } \\
\text { \& Yan, 2016; Kim, Jeong, Clayton, Haberl, \& Yan, 2015; Zhang, Teizer, } \\
\text { Pradhananga, \& Eastman, 2015; Wang, Cho, \& Kim, 2015; Ben-Alon \& } \\
\text { Sacks, 2017; Laefer \& Truong-Hong, 2017; Kim, C., Son, \& Kim, C., 2013a) }\end{array}$ \\
\hline & 3.3. Application of newest technologies & $\begin{array}{l}\text { clouds in (Jiao, Zhang, Li, Wang, \& Yang, 2013; Anil, Tang, Akinci, \& Huber, } \\
\text { 2013), gbXML (Ham \& Golparvar-Fard, 2015) }\end{array}$ \\
\hline & $\begin{array}{l}\text { 3.4. Web technologies (including } \\
\text { Semantic Web) }\end{array}$ & (Ding, Zhong, Wu, \& Luo, 2016; Bilal et al., 2017; Chen \& Nguyen, 2016) \\
\hline & 3.5. Goal-driven approach & (Won \& Lee, 2016) \\
\hline & 3.6. Information mapping & (Kim et al., 2016b) \\
\hline & $\begin{array}{l}\text { 3.7. Information modelling and } \\
\text { management }\end{array}$ & $\begin{array}{l}\text { (Volkov, Chelyshkov, \& Lysenko, 2016; Lee, Y. C., Eastman, \& Lee, J. K., } \\
\text { 2015a; Han \& Golparvar-Fard, 2017; Mazairac \& Beetz, 2013) }\end{array}$ \\
\hline & 3.8. Visualisation & $\begin{array}{l}\text { (Irizarry, Karan, \& Jalaei, 2013; Rolfsen \& Merschbrock, 2016; Niu, Pan, \& } \\
\text { Zhao, 2015) } \\
\text { Real time visualization of BIM (Johansson, Roupé, \& Bosch-Sijtsema, 2015) }\end{array}$ \\
\hline
\end{tabular}


End of Table 8

\begin{tabular}{|c|c|c|}
\hline $\begin{array}{l}\text { BIM } \\
\text { application } \\
\text { areas }\end{array}$ & Sub area & Resource \\
\hline & $\begin{array}{l}\text { 3.9. Analysis using patterns, } \\
\text { semantic analysis }\end{array}$ & $\begin{array}{l}\text { (Yalcinkaya \& Singh, 2015; Lee, Oh, Kim, \& Choi, 2015; Costa \& Madrazo, } \\
\text { 2015) }\end{array}$ \\
\hline & $\begin{array}{l}\text { 3.10. Knowledge application, } \\
\text { Reasoning }\end{array}$ & $\begin{array}{l}\text { (Kim \& Cho, 2015; Motawa \& Almarshad, 2013; Han, Cline, \& Golparvar- } \\
\text { Fard, 2015; Venugopal, Eastman, \& Teizer, 2015; Singh, Sawhney, \& } \\
\text { Borrmann, 2015; Lee, Chi, Wang, Wang, \& Park, 2016; Lee, Eastman, \& } \\
\text { Solihin, 2016a; Shad, Khorrami, \& Ghaemi, 2017) }\end{array}$ \\
\hline \multirow[b]{2}{*}{$\begin{array}{l}\text { 4. Standards } \\
\text { and quality } \\
\text { assurance }\end{array}$} & 4.1. Quality management or assurance & (Chen \& Luo, 2014; Kim et al., 2016a) \\
\hline & 4.2. Safety planning and checking & $\begin{array}{l}\text { (Kim, Cho, \& Zhang, 2016; Ganah \& John, 2015; Zhang et al., 2015a; Zhang, } \\
\text { Teizer, Lee, Eastman, \& Venugopal, 2013; Choi, J., Choi, J., \& Kim, 2014; } \\
\text { Zhang, Wu, Zhu, \& AbouRizk, 2017) }\end{array}$ \\
\hline \multirow{3}{*}{$\begin{array}{l}\text { 5. Environ- } \\
\text { ment }\end{array}$} & 5.1. Gas emission & (Giesekam, Barrett, Taylor, \& Owen, 2014; Motawa \& Carter, 2013) \\
\hline & 5.2. Green building & $\begin{array}{l}\text { (Ilhan \& Yaman, 2016; Wong \& Zhou, 2015; Chen \& Nguyen, 2016; Shad } \\
\text { et al., 2017) }\end{array}$ \\
\hline & 5.3. Life quality and health & (Li, Su, Zhang, \& Kong, 2017; Takim, Harris, \& Nawawi, 2013) \\
\hline 6. Materials & & $\begin{array}{l}\text { (Han \& Golparvar-Fard, 2015; Hoxha, Habert, Lasvaux, Chevalier, \& Le } \\
\text { Roy, 2017) }\end{array}$ \\
\hline
\end{tabular}

As shown in Table 8, mainly papers published in 20152017 of are reviewed and presented.

As the literature review shows, the BIM surveys and systematic literature reviews on BIM are more and more popular. Authors analyse BIM and related technologies according to different topics. Table 9 below illustrates a review of results on BIM literature reviews presented in
Section 3.1.4. In the future, it may be supplemented by more details.

As illustrated in Table 9, the majority are literature reviews. Only some (2, 4 and 9) are supplemented by questioning. BIM research covers quite a wide range of topics (see Table 9 last column). However, the reviewed authors identify both advantages and disadvantages of BIM.

Table 9. Results of BIM literature reviews

\begin{tabular}{|c|c|c|c|c|c|}
\hline No. & Source & $\begin{array}{l}\text { Review period } \\
\text { in years }\end{array}$ & Type of review & $\begin{array}{c}\text { Number of analysed } \\
\text { sources }\end{array}$ & Topic \\
\hline 1 & $\begin{array}{l}\text { (Eleftheriadis } \\
\text { et al., 2017) }\end{array}$ & $2009-2014$ & Literature review & 170 articles & $\begin{array}{l}\text { BIM capabilities based on life cycle energy } \\
\text { efficiency in building structures }\end{array}$ \\
\hline 2 & $\begin{array}{l}\text { (Soust-Verdaguer } \\
\text { et al., 2016a) }\end{array}$ & $2012-2016$ & $\begin{array}{l}\text { Literature } \\
\text { review }+ \text { case } \\
\text { analyses }\end{array}$ & $\begin{array}{l}>37 \text { publications }+ \\
20 \text { cases }\end{array}$ & $\begin{array}{l}\text { To identify the simplification strategies } \\
\text { assumed in each paper, to clarify and to help } \\
\text { to promote further developments on LCA of } \\
\text { single-family houses }\end{array}$ \\
\hline 3 & $\begin{array}{l}\text { (Soust-Verdaguer } \\
\text { et al., 2016b) }\end{array}$ & $2013-2015$ & Literature review & 180 publications & recent studies centred on BIM-based LCA \\
\hline 4 & $\begin{array}{l}\text { (Shou et al., } \\
\text { 2015) }\end{array}$ & $2006-2014$ & $\begin{array}{l}\text { Literature } \\
\text { review + case } \\
\text { analyses }\end{array}$ & $\begin{array}{l}40 \text { case studies in } \\
\text { academic journals and } \\
\text { conference proceedings } \\
\text { and } 24 \text { BIM cases in } \\
\text { industrial reports }\end{array}$ & $\begin{array}{l}\text { BIM implementation in building and } \\
\text { infrastructure industries }\end{array}$ \\
\hline 5 & $\begin{array}{l}\text { (Chen et al., } \\
\text { 2015) }\end{array}$ & $2005-2014$ & Literature review & 75 papers & $\begin{array}{l}\text { synchronizing information between BIM and } \\
\text { real-life building processes }\end{array}$ \\
\hline 6 & $\begin{array}{l}\text { (Volk et al., } \\
\text { 2014) }\end{array}$ & $2002-2012$ & Literature review & 180 publications & $\begin{array}{l}\text { BIM implementation and research in } \\
\text { existing buildings }\end{array}$ \\
\hline 7 & $\begin{array}{l}\text { (Merschbrock \& } \\
\text { Munkvold, 2012) }\end{array}$ & $2011-2012$ & $\begin{array}{l}\text { Literature review } \\
\text { (scoping study) }\end{array}$ & 264 articles & $\begin{array}{l}\text { the extent, range and nature of the research } \\
\text { activity on three-dimensional BIM topics }\end{array}$ \\
\hline 8 & (Cerovsek, 2011) & $2000-2009$ & Literature review & $\begin{array}{l}\text { over } 150 \mathrm{AEC} / \mathrm{O} \text { tools } \\
\text { and digital models }\end{array}$ & $\begin{array}{l}\text { comprehensive recommendations for their } \\
\text { advancement and development }\end{array}$ \\
\hline 9 & $\begin{array}{l}\text { (Yan \& Damian, } \\
\text { 2008) }\end{array}$ & $\begin{array}{c}\text { From early past } \\
\text { till now } \\
2007-2008\end{array}$ & $\begin{array}{l}\text { Literature } \\
\text { review }+ \\
\text { questioning }\end{array}$ & $\begin{array}{l}67 \text { individuals from } \\
\text { the AEC industry }\end{array}$ & $\begin{array}{l}\text { the historical evolution of design tools } \\
\text { BIM adoption, perceived benefits, and } \\
\text { perceived barriers }\end{array}$ \\
\hline 10 & Our review & $1990-2016$ & Literature review & $\begin{array}{l}3 \text { databases, main } \\
9 \text { sources }\end{array}$ & The breadth of available literature on BIM \\
\hline
\end{tabular}


In some research, like in (Cerovsek, 2011; Shou et al., 2015; Soust-Verdaguer et al., 2016a), guidelines and/or recommendations for improvement and usage of BIM technologies are provided. Sun, Jiang, Skibniewski, Man, and Shen (2017) identify many factors still limiting the application of BIM in the construction industry. Authors identify twenty-two sub-factors and classify them into five categories: Technology, Cost, Management, Personnel, and Legal. They also present some suggestions for eliminating these limiting factors. Moreover, authors, like (Chen et al., 2015), work on development of frameworks for information synchronization and management, decision making and technologies development for BIM and real-life building processes.

\subsection{Future BIM trends}

According to the analysed literature on BIM, different trends of BIM evolvement and publications have been found. In this section, the main directions of BIM development are presented.

Six main directions discovered in contemporary papers are presented in Figure 5. They are as follows. The Construction Process category covers the construction process of a building as it is, including analysis of parts of the buildings, such as energy production, daylighting, etc. Computer Sciences covers different information technologies and approaches used to manage, optimise, visualize and automate the construction process, information and resources required in the construction of a building. Environment covers the concept of a green building. Education and training covers human role in BIM. Case Studies describes different BIM case studies within an industry set-

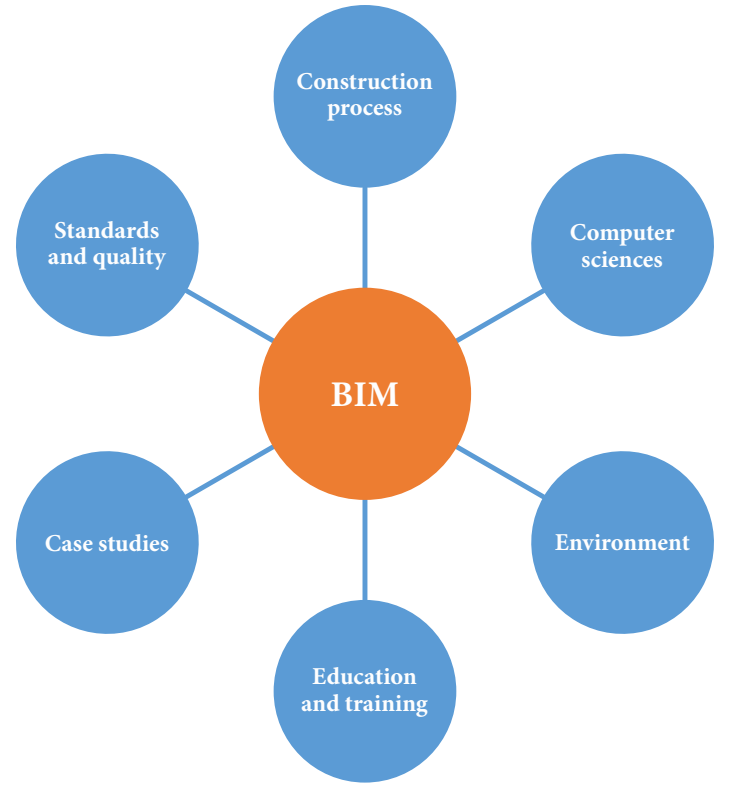

Figure 5. Current situation of the BIM evolvement

tings. Standards covers topics on applied and implemented standards, regulations and norms in BIM, including quality management, assurance, and safety planning. There are some other fields to be found in BIM publications, but those six fields are the major ones.

The authors of this publication believe that such distribution and interest in BIM areas is determined by the following factors: global concern about energy saving, rapid growth of information technologies and social-economic progress.

Table 10. MCDM in BIM

\begin{tabular}{|c|c|}
\hline MCDM applied & Application area \\
\hline Fuzzy MCDM & $\begin{array}{l}\text { - low-carbon building measures selection using fuzzy PROMETHEE (Chen \& Pan, 2016) } \\
\text { - bridge information modelling and cost estimation at conceptual design stage of concrete box-girder bridges } \\
\text { (Markiz \& Jrade, 2014; Zavadskas \& Vilutiene, 2006) } \\
\text { - evaluating renewable energy alternatives in Turkey (Balin \& Baraçli, 2017) }\end{array}$ \\
\hline $\begin{array}{l}\text { Compex MCDM or } \\
\text { hybrid models }\end{array}$ & $\begin{array}{l}\text { The environmental impacts of three alternative types of envelopes (masonry, log and timber frame) of an } \\
\text { energy efficient single-family house, simultaneously identifying the most rational alternative according to the } \\
\text { considered criteria (reduction of expenses, non-renewable primary energy, Green House Gases and ozone layer } \\
\text { depletion) (Motuziene, Rogoža, Lapinskiene, \& Vilutiene,, 2016). Authors use the method of multiple criteria } \\
\text { COmplex PRoportional ASsesment (COPRAS) (Kaklauskas et al., 2006) and AHP (Analytic Hierarchy Process). } \\
\text { In (Yeh, 2017) authors employ a MCDM approach by using the interpretive structural modelling (ISM) method } \\
\text { to deal with the interrelationship among criteria, and the analytic network process (ANP) method is employed } \\
\text { to determine the relative weights of each criterion. Finally, in order to choose the alternative for the ideal } \\
\text { solution of this problem TOPSIS is used. In (Turskis, Morkunaite, \& Kutut, 2017) authors propose using of a } \\
\text { hybrid model developed for ranking the heritage buildings intended for renovation according to their value. } \\
\text { In (Valipour, Yahaya, Md Noor, Mardani, \& Antuchevičiene, 2016) authors present an approach in the form of } \\
\text { a hybrid Fuzzy method and Cybernetic Analytic Network Process (CANP) model for identifying shared risks. } \\
\text { In (Hosseini, Lale Arefi, Bitarafan, Abazarlou, \& Zavadskas, 2016) authors use the comparison of FUZZY and } \\
\text { AHP to study different types of exterior walls for renewal and reconstruction of buildings in the earthquake area }\end{array}$ \\
\hline $\begin{array}{l}\text { AHP (Analytic } \\
\text { Hierarchy Process) }\end{array}$ & $\begin{array}{l}\text { - Building simulations supporting decision making in early design (Østergård, Jensen, \& Maagaard, 2016) } \\
\text { - A MCDM with BIM for fall protection planning (Melzner, Hollermann, \& Bargstadt, 2012) }\end{array}$ \\
\hline $\begin{array}{l}\text { WASPAS (Weighted } \\
\text { Aggregated } \\
\text { Sum Product } \\
\text { Assessment) }\end{array}$ & $\begin{array}{l}\text { Weighted Aggregated Sum Product Assessment method with Grey attributes scores (WASPAS-G) with BIM } \\
\text { for old equipment factory redevelopment (Pavlovskis, Antucheviciene, \& Migilinskas, 2016) }\end{array}$ \\
\hline TOPSIS & $\begin{array}{l}\text { Integrating decision support system and BIM to optimise the selection of sustainable building components } \\
\text { (Jalaei, Jrade, \& Nassiri, 2015) }\end{array}$ \\
\hline
\end{tabular}




\subsection{Possible extension of BIM by MCDM}

A narrow and new developing area in BIM is the application of Multi-Criteria Decision Making (MCDM) methods for selection of appropriate alternatives in different construction areas. Research results in chosen databases shows that there are few related articles, and some of them are presented in Table 10.

\section{Conclusions}

As the systematic literature review shows, BIM becoming widely used in construction. It offers a number of advantages and new opportunities of improvement of efficiency and effectiveness of the construction process and enhancing the use of emerging technology throughout a project's lifecycle, not only in new buildings, but also in existing buildings, including overall infrastructures. However, as a new approach, it has disadvantages which should be overcome in the future.

As the current research shows, the main areas of developing BIM are as follows: the construction process, application of new approaches and technologies drawn from computer science, environment improvement through BIM usage, published case studies on BIM usage, standards and quality implementation in BIM, and BIM staff training and education.

However, as was found in related works, the main drawback of BIM application is lack of skilled staff (Ghaffarianhoseini et al., 2017). Therefore, the project management process is still unclear, and companies without experience with BIM might also be excluded from tendering future BIM-enabled projects (Ghaffarianhoseini et al., 2017).

Moreover, the current research shows that BIM can be extended by MCDM methods for selection of appropriate alternatives in different construction areas. Research in this field is only now beginning to grow.

Unfortunately, too little attention is devoted to the extended concept of BIM, i.e. BLM (Building Lifecycle Modelling). We then have to do with 7D modelling. BLM, by definition, covers the management of the building's life cycle, and is also closely related to the design of nearly zero-energy buildings (nZEB). The use of these concepts in engineering practice is the foundation for a holistic approach to the investment process, i.e. the Integrated Project Delirevery (IPD).

\section{References}

Abanda, F. H., \& Byers, L. (2016). An investigation of the impact of building orientation on energy consumption in a domestic building using emerging BIM (Building Information Modelling). Energy, 97, 517-527.

https://doi.org/10.1016/j.energy.2015.12.135

Ahn, K. U., Kim, Y. J., Park, C. S., Kim, I., \& Lee, K. (2014). BIM interface for full vs. semi-automated building energy simulation. Energy and Buildings, 68, 671-678.

https://doi.org/10.1016/j.enbuild.2013.08.063
Alwan, Z., Jones, P., \& Holgate, P. (2017). Strategic sustainable development in the UK construction industry, through the framework for strategic sustainable development, using Building Information Modelling. Journal of Cleaner Production, 140(1), 349-358. https://doi.org/10.1016/j.jclepro.2015.12.085

Amor, R., Betts, M., Coetzee, G., \& Sexton, M. (2002). Information technology for construction: recent work and future directions. Journal of Information Technology in Construction, 7(16), 245-258.

Anil, E. B., Tang, P., Akinci, B., \& Huber, D. (2013). Deviation analysis method for the assessment of the quality of the asis building information models generated from point cloud data. Automation in Construction, 35, 507-516. https://doi.org/10.1016/j.autcon.2013.06.003

Anumba, C. E., Dainty, A., Ison, S., \& Sergeant, A. (2006). Understanding structural and cultural impediments to ICT system integration: A GIS-based case study. Engineering, Construction and Architectural Management, 13(6), 616-633. https://doi.org/10.1108/09699980610712409

Anumba, C. J. (2016). Past, present and future directions in Building Information Modelling (BIM). Retrieved from http:// www.gcu.ac.uk/ebe/media/gcalwebv2/business/Chimay\%20 BIM\%20Seminar.pdf

Arayici, Y., Coates, P., Koskela, L., Kagioglou, M., Usher, C., \& O'reilly, K. (2011). Technology adoption in the BIM implementation for lean architectural practice. Automation in Construction, 20(2), 189-195.

https://doi.org/10.1016/j.autcon.2010.09.016

Aranda-Mena, G., Crawford, J., Chevez, A., \& Froese, T. (2009). Building information modelling demystified: does it make business sense to adopt BIM?. International Journal of Managing Projects in Business, 2(3), 419-434. https://doi.org/10.1108/17538370910971063

Arksey, H., \& O'Malley, L. (2005). Scoping studies: towards a methodological framework. International Journal of Social Research Methodology, 8(1), 19-32. https://doi.org/10.1080/1364557032000119616

Atazadeh, B., Kalantari, M., Rajabifard, A., \& Ho, S. (2017). Modelling building ownership boundaries within BIM environment: A case study in Victoria, Australia. Computers, Environment and Urban Systems, 61, 24-38. https://doi.org/10.1016/j.compenvurbsys.2016.09.001

Azhar, S. (2011). Building information modeling (BIM): Trends, benefits, risks, and challenges for the AEC industry. Leadership and Management in Engineering, 11(3), 241-252. https://doi.org/10.1061/(ASCE)LM.1943-5630.0000127

Azzouz, A., Borchers, M., Moreira, J., \& Mavrogianni, A. (2017). Life cycle assessment of energy conservation measures during early stage office building design: A case study in London, UK. Energy and Buildings, 139, 547-568. https://doi.org/10.1016/j.enbuild.2016.12.089

Balin, A., \& Baraçli, H. (2017). A fuzzy multi-criteria decision making methodology based upon the interval type-2 fuzzy sets for evaluating renewable energy alternatives in Turkey. Technological and Economic Development of Economy, 23(5), 742-763. https://doi.org/10.3846/20294913.2015.1056276

Ben-Alon, L., \& Sacks, R. (2017). Simulating the behavior of trade crews in construction using agents and building information modeling. Automation in Construction, 74, 12-27. https://doi.org/10.1016/j.autcon.2016.11.002

Biagini, C., Capone, P., Donato, V., \& Facchini, N. (2016). Towards the BIM implementation for historical building restoration sites. Automation in Construction, 71(1), 74-86. https://doi.org/10.1016/j.autcon.2016.03.003 
Bilal, M., Oyedele, L. O., Munir, K., Ajayi, S. O., Akinade, O. O., Owolabi, H. A., \& Alaka, H. A. (2017). The application of web of data technologies in building materials information modelling for construction waste analytics. Sustainable Materials and Technologies, 11, 28-37.

https://doi.org/10.1016/j.susmat.2016.12.004

Björk, B. C. (1999). Information Technology in Construction-domain definition and research issues. Retrieved from https://helda.helsinki.fi/bitstream/handle/10227/617/bjork. pdf; sequence $=2$

Borgstein, E. H., Lamberts, R., \& Hensen, J. L. M. (2016). Evaluating energy performance in non-domestic buildings: A review. Energy and Buildings, 128, 734-755.

https://doi.org/10.1016/j.enbuild.2016.07.018

Cao, D., Wang, G., Li, H., Skitmore, M., Huang, T., \& Zhang, W. (2015). Practices and effectiveness of building information modelling in construction projects in China. Automation in Construction, 49, 113-122.

https://doi.org/10.1016/j.autcon.2014.10.014

Cerovsek, T. (2011). A review and outlook for a 'Building Information Model'(BIM): A multi-standpoint framework for technological development. Advanced Engineering Informatics, 25(2), 224-244. https://doi.org/10.1016/j.aei.2010.06.003

Chen, K., Lu, W., Peng, Y., Rowlinson, S., \& Huang, G. Q. (2015). Bridging BIM and building: From a literature review to an integrated conceptual framework. International Journal of Project Management, 33(6), 1405-1416.

https://doi.org/10.1016/j.ijproman.2015.03.006

Chen, L., \& Luo, H. (2014). A BIM-based construction quality management model and its applications. Automation in Construction, 46, 64-73.

https://doi.org/10.1016/j.autcon.2014.05.009

Chen, L., \& Pan, W. (2016). BIM-aided variable fuzzy multicriteria decision making of low-carbon building measures selection. Sustainable Cities and Society, 27, 222-232. https://doi.org/10.1016/j.scs.2016.04.008

Chen, P. H., \& Nguyen, T. C. (2016). Integrating BIM and Web Map Service (WMS) for Green Building Certification. Procedia Engineering, 164, 503-509.

https://doi.org/10.1016/j.proeng.2016.11.651

Choi, J., Choi, J., \& Kim, I. (2014). Development of BIM-based evacuation regulation checking system for high-rise and complex buildings. Automation in Construction, 46, 38-49. https://doi.org/10.1016/j.autcon.2013.12.005

Choi, J., Kim, H., \& Kim, I. (2015). Open BIM-based quantity take-off system for schematic estimation of building frame in early design stage. Journal of Computational Design and Engineering, 2(1), 16-25.

https://doi.org/10.1016/j.jcde.2014.11.002

Chwieduk, D. (2003). Towards sustainable-energy buildings. Applied Energy, 76(1), 211-217. https://doi.org/10.1016/S0306-2619(03)00059-X

Ciribini, A. L. C., Ventura, S. M., \& Paneroni, M. (2016). Implementation of an interoperable process to optimise design and construction phases of a residential building: A BIM Pilot Project. Automation in Construction, 71(1), 62-73. https://doi.org/10.1016/j.autcon.2016.03.005

Costa, G., \& Madrazo, L. (2015). Connecting building component catalogues with BIM models using semantic technologies: An application for precast concrete components. Automation in Construction, 57, 239-248.

https://doi.org/10.1016/j.autcon.2015.05.007

Delone, W. H., \& McLean, E. R. (2003). The DeLone and McLean model of information systems success: a ten-year update. Journal of Management Information Systems, 19(4), 9-30. https://doi.org/10.1080/07421222.2003.11045748
Di, G. M. (2015). BIM and energy efficient retrofitting in school buildings. Energy Procedia, 78(November), 1045-1050.

Ding, L. Y., Zhong, B. T., Wu, S., \& Luo, H. B. (2016). Construction risk knowledge management in BIM using ontology and semantic web technology. Safety Science, 87, 202-213. https://doi.org/10.1016/j.ssci.2016.04.008

Eleftheriadis, S., Mumovic, D., \& Greening, P. (2017). Life cycle energy efficiency in building structures: A review of current developments and future outlooks based on BIM capabilities. Renewable and Sustainable Energy Reviews, 67, 811-825. https://doi.org/10.1016/j.rser.2016.09.028

Gal, U., Lyytinen, K., \& Yoo, Y. (2008). The dynamics of IT boundary objects, information infrastructures, and organisational identities: The introduction of 3D modelling technologies into the architecture, engineering, and construction industry. European Journal of Information Systems, 17(3), 290304. https://doi.org/10.1057/ejis.2008.13

Ganah, A., \& John, G. A. (2015). Integrating building information modeling and health and safety for onsite construction. Safety and Health at Work, 6(1), 39-45.

https://doi.org/10.1016/j.shaw.2014.10.002

Gao, G., Liu, Y. S., Lin, P., Wang, M., Gu, M., \& Yong, J. H. (2015). BIMTag: Concept-based automatic semantic annotation of online BIM product resources. Advanced Engineering Informatics, 31, 48-61. https://doi.org/10.1016/j.aei.2015.10.003

Ghaffarianhoseini, A., Tookey, J., Ghaffarianhoseini, A., Naismith, N., Azhar, S., Efimova, O., \& Raahemifar, K. (2017). Building Information Modelling (BIM) uptake: Clear benefits, understanding its implementation, risks and challenges. Renewable and Sustainable Energy Reviews, 75, 1046-1053. https://doi.org/10.1016/j.rser.2016.11.083

Giesekam, J., Barrett, J., Taylor, P., \& Owen, A. (2014). The greenhouse gas emissions and mitigation options for materials used in UK construction. Energy and Buildings, 78, 202-214. https://doi.org/10.1016/j.enbuild.2014.04.035

Gourlis, G., \& Kovacic, I. (2016). Building Information Modelling for analysis of energy efficient industrial buildings - A case study. Renewable and Sustainable Energy Reviews, 68(2), 953-963.

Guo, S. J., \& Wei, T. (2016). Cost-effective energy saving measures based on BIM Technology: Case study at National Taiwan University. Energy and Buildings, 127, 433-441. https://doi.org/10.1016/j.enbuild.2016.06.015

Ham, Y., \& Golparvar-Fard, M. (2015). Mapping actual thermal properties to building elements in gbXML-based BIM for reliable building energy performance modeling. Automation in Construction, 49, 214-224.

https://doi.org/10.1016/j.autcon.2014.07.009

Han, K. K., \& Golparvar-Fard, M. (2015). Appearance-based material classification for monitoring of operation-level construction progress using 4D BIM and site photologs. Automation in Construction, 53, 44-57.

https://doi.org/10.1016/j.autcon.2015.02.007

Han, K. K., \& Golparvar-Fard, M. (2017). Potential of big visual data and building information modeling for construction performance analytics: An exploratory study. Automation in Construction, 73, 184-198. https://doi.org/10.1016/j.autcon.2016.11.004

Han, K. K., Cline, D., \& Golparvar-Fard, M. (2015). Formalized knowledge of construction sequencing for visual monitoring of work-in-progress via incomplete point clouds and lowLoD 4D BIMs. Advanced Engineering Informatics, 29(4), 889901. https://doi.org/10.1016/j.aei.2015.10.006

Hongling, G., Yantao, Y., Weisheng, Z., \& Yan, L. (2016). BIM and safety rules based automated identification of unsafe design factors in construction. Procedia Engineering, 164, 467472. https://doi.org/10.1016/j.proeng.2016.11.646 
Hosseini, S. T., Lale Arefi, S., Bitarafan, M., Abazarlou, S., \& Zavadskas, E. K. (2016). Evaluation types of exterior walls to reconstruct Iran earthquake areas (Ahar Heris Varzeqan) by using AHP and fuzzy methods. International Journal of Strategic Property Management, 20(3), 328-340. https://doi.org/10.3846/1648715X.2016.1190794

Hoxha, E., Habert, G., Lasvaux, S., Chevalier, J., \& Le Roy, R. (2017). Influence of construction material uncertainties on residential building LCA reliability. Journal of Cleaner Production, 144, 33-47. https://doi.org/10.1016/j.jclepro.2016.12.068

Ilhan, B., \& Yaman, H. (2016). Green building assessment tool (GBAT) for integrated BIM-based design decisions. Automation in Construction, 70, 26-37.

https://doi.org/10.1016/j.autcon.2016.05.001

Irizarry, J., Karan, E. P., \& Jalaei, F. (2013). Integrating BIM and GIS to improve the visual monitoring of construction supply chain management. Automation in Construction, 31, 241-254. https://doi.org/10.1016/j.autcon.2012.12.005

Isikdag, U., \& Underwood, J. (2010, May). A synopsis of the handbook of research on building information modeling. In Proceedings of CIB 2010 World Building Congress (pp. 84-96). Salford, MA, USA.

Jalaei, F., Jrade, A., \& Nassiri, M. (2015). Integrating Decision Support System (DSS) and Building Information Modeling (BIM) to optimize the selection of sustainable building components. Journal of Information Technology in Construction (ITcon), 20(25), 399-420.

Jia, M., Srinivasan, R. S., \& Raheem, A. A. (2017). From occupancy to occupant behavior: An analytical survey of data acquisition technologies, modeling methodologies and simulation coupling mechanisms for building energy efficiency. Renewable and Sustainable Energy Reviews, 68, 525-540. https://doi.org/10.1016/j.rser.2016.10.011

Jiao, Y., Zhang, S., Li, Y., Wang, Y., \& Yang, B. (2013). Towards cloud augmented reality for construction application by BIM and SNS integration. Automation in Construction, 33, 37-47. https://doi.org/10.1016/j.autcon.2012.09.018

Johansson, M., Roupé, M., \& Bosch-Sijtsema, P. (2015). Realtime visualization of building information models (BIM). Automation in Construction, 54, 69-82. https://doi.org/10.1016/j. autcon.2015.03.018

Juan, Y. K., Lai, W. Y., \& Shih, S. G. (2017). Building information modeling acceptance and readiness assessment in Taiwanese architectural firms. Journal of Civil Engineering and Management, 23(3), 356-367.

https://doi.org/10.3846/13923730.2015.1128480

Jung, Y., \& Joo, M. (2011). Building information modelling (BIM) framework for practical implementation. Automation in Construction, 20(2), 126-133.

https://doi.org/10.1016/j.autcon.2010.09.010

Kaklauskas, A., Zavadskas, E. K., Raslanas, S., Ginevicius, R., Komka, A., \& Malinauskas, P. (2006). Selection of low-e windows in retrofit of public buildings by applying multiple criteria method COPRAS: A Lithuanian case. Energy and Buildings, 38(5), 454-462.

https://doi.org/10.1016/j.enbuild.2005.08.005

Khaddaj, M., \& Srour, I. (2016). Using BIM to Retrofit existing buildings. Procedia Engineering, 145, 1526-1533. https://doi.org/10.1016/j.proeng.2016.04.192

Kim, C., Son, H., \& Kim, C. (2013a). Automated construction progress measurement using a $4 \mathrm{D}$ building information model and 3D data. Automation in Construction, 31, 75-82. https://doi.org/10.1016/j.autcon.2012.11.041

Kim, H., Anderson, K., Lee, S., \& Hildreth, J. (2013). Generating construction schedules through automatic data extraction us- ing open BIM (building information modeling) technology. Automation in Construction, 35, 285-295.

https://doi.org/10.1016/j.autcon.2013.05.020

Kim, H., Shen, Z., Kim, I., Kim, K., Stumpf, A., \& Yu, J. (2016b). BIM IFC information mapping to building energy analysis (BEA) model with manually extended material information. Automation in Construction, 68, 183-193. https://doi.org/10.1016/j.autcon.2016.04.002

Kim, J. B., Jeong, W., Clayton, M. J., Haberl, J. S., \& Yan, W. (2015). Developing a physical BIM library for building thermal energy simulation. Automation in Construction, 50, 1628. https://doi.org/10.1016/j.autcon.2014.10.011

Kim, K., \& Cho, Y. K. (2015). Construction-specific spatial information reasoning in Building Information Models. Advanced Engineering Informatics, 29(4), 1013-1027. https://doi.org/10.1016/j.aei.2015.08.004

Kim, K., Cho, Y., \& Zhang, S. (2016). Integrating work sequences and temporary structures into safety planning: Automated scaffolding-related safety hazard identification and prevention in BIM. Automation in Construction, 70, 128-142.

https://doi.org/10.1016/j.autcon.2016.06.012

Kim, M. K., Wang, Q., Park, J. W., Cheng, J. C., Sohn, H., \& Chang, C. C. (2016a). Automated dimensional quality assurance of full-scale precast concrete elements using laser scanning and BIM. Automation in Construction, 72, 102-114. https://doi.org/10.1016/j.autcon.2016.08.035

Kitchenham, B., Mendes, E., \& Travassos, G. H. (2007). Cross versus within-company cost estimation studies: A systematic review. IEEE Transactions on Software Engineering, 33(5), 316-329. https://doi.org/10.1109/TSE.2007.1001

Kota, S., Haberl, J. S., Clayton, M. J., \& Yan, W. (2014). Building Information Modeling (BIM)-based daylighting simulation and analysis. Energy and Buildings, 81, 391-403. https://doi.org/10.1016/j.enbuild.2014.06.043

Kreiner, H., Passer, A., \& Wallbaum, H. (2015). A new systemic approach to improve the sustainability performance of office buildings in the early design stage. Energy and Buildings, 109, 385-396. https://doi.org/10.1016/j.enbuild.2015.09.040

Kumar, S. S., \& Cheng, J. C. (2015). A BIM-based automated site layout planning framework for congested construction sites. Automation in Construction, 59, 24-37.

https://doi.org/10.1016/j.autcon.2015.07.008

Kuo, H. J., Hsieh, S. H., Guo, R. C., \& Chan, C. C. (2016). A verification study for energy analysis of BIPV buildings with BIM. Energy and Buildings, 130, 676-691. https://doi.org/10.1016/j.enbuild.2016.08.048

Laefer, D. F., \& Truong-Hong, L. (2017). Toward automatic generation of 3D steel structures for building information modelling. Automation in Construction, 74, 66-77. https://doi.org/10.1016/j.autcon.2016.11.011

Lee, D. Y., Chi, H. L., Wang, J., Wang, X., \& Park, C. S. (2016). A linked data system framework for sharing construction defect information using ontologies and BIM environments. Automation in Construction, 68, 102-113. https://doi.org/10.1016/j.autcon.2016.05.003

Lee, H. W., Oh, H., Kim, Y., \& Choi, K. (2015). Quantitative analysis of warnings in building information modeling (BIM). Automation in Construction, 51, 23-31. https://doi.org/10.1016/j.autcon.2014.12.007

Lee, Y. C., Eastman, C. M., \& Lee, J. K. (2015a). Validations for ensuring the interoperability of data exchange of a building information model. Automation in Construction, 58, 176-195. https://doi.org/10.1016/j.autcon.2015.07.010

Lee, Y. C., Eastman, C. M., \& Solihin, W. (2016a). An ontologybased approach for developing data exchange requirements 
and model views of building information modeling. Advanced Engineering Informatics, 30(3), 354-367.

https://doi.org/10.1016/j.aei.2016.04.008

Lee, S. K., Kim, K. R., \& Yu, J. H. (2014). BIM and ontologybased approach for building cost estimation. Automation in Construction, 41, 96-105.

https://doi.org/10.1016/j.autcon.2013.10.020

Li, X., Su, S., Zhang, Z., \& Kong, X. (2017). An integrated environmental and health performance quantification model for pre-occupancy phase of buildings in China. Environmental Impact Assessment Review, 63, 1-11. https://doi.org/10.1016/j.eiar.2016.11.003

Liao, L., \& Teo, E. A. L. (2017). Critical Success Factors for enhancing the Building Information Modelling implementation in building projects in Singapore. Journal of Civil Engineering and Management, 23(8), 1029-1044.

https://doi.org/10.3846/13923730.2017.1374300

Liu, S., Meng, X., \& Tam, C. (2015). Building information modeling based building design optimization for sustainability. Energy and Buildings, 105, 139-153.

https://doi.org/10.1016/j.enbuild.2015.06.037

Lu, W., Webster, C., Chen, K., Zhang, X., \& Chen, X. (2017). Computational Building Information Modelling for construction waste management: Moving from rhetoric to reality. Renewable and Sustainable Energy Reviews, 68, 587-595. https://doi.org/10.1016/j.rser.2016.10.029

Ma, Z., \& Liu, Z. (2014). BIM-based intelligent acquisition of construction information for cost estimation of building projects. Procedia Engineering, 85, 358-367.

https://doi.org/10.1016/j.proeng.2014.10.561

Markiz, N., \& Jrade, A. (2014). Integrating a fuzzy-logic decision support system with bridge information modelling and cost estimation at conceptual design stage of concrete box-girder bridges. International Journal of Sustainable Built Environment, 3(1), 135-152.

https://doi.org/10.1016/j.ijsbe.2014.08.002

Matthews, J., Love, P. E., Heinemann, S., Chandler, R., Rumsey, C., \& Olatunj, O. (2015). Real time progress management: Reengineering processes for cloud-based BIM in construction. Automation in Construction, 58, 38-47.

https://doi.org/10.1016/j.autcon.2015.07.004

Matthews, J., Love, P. E., Mewburn, J., Stobaus, C., \& Ramanayaka, C. (2018). Building information modelling in construction: Insights from collaboration and change management perspectives. Production Planning \& Control, 29(3), 202-216. https://doi.org/10.1080/09537287.2017.1407005

Mazairac, W., \& Beetz, J. (2013). BIMQL - An open query language for building information models. Advanced Engineering Informatics, 27(4), 444-456.

https://doi.org/10.1016/j.aei.2013.06.001

McArthur, J. J. (2015). A building information management (BIM) framework and supporting case study for existing building operations, maintenance and sustainability. Procedia Engineering, 118, 1104-1111. https://doi.org/10.1016/j.proeng.2015.08.450

Melville, N., Kraemer, K., \& Gurbaxani, V. (2004). Review: Information technology and organizational performance: An integrative model of IT business value. MIS Quarterly, 28(2), 283-322. https://doi.org/10.2307/25148636

Melzner, J., Hollermann, S., \& Bargstadt, H. J. (2012). A multicriteria decision-support approach for fall protection planning. In G. Gudnason, \& R. Scherer (Eds.), Proc. of $9^{\text {th }} \mathrm{Eu}$ ropean Conference on Product and Process Modelling, Ework and Ebusiness in Architecture, Engineering and Construction, 25-27 July 2012 (pp. 675-680). Reykjavik, Iceland. https://doi.org/10.1201/b12516-107
Merschbrock, C., \& Munkvold, B. E. (2012). A Research Review on Building Information Modeling in Construction - An Area Ripe for IS Research. Communications of the Association for Information Systems, 31(1), 10.

Merschbrock, C., \& Munkvold, B. E. (2015). Effective digital collaboration in the construction industry - A case study of BIM deployment in a hospital construction project. Computers in Industry, 73, 1-7. https://doi.org/10.1016/j.compind.2015.07.003

Migilinskas, D., Popov, V., Juocevicius, V., \& Ustinovichius, L. (2013). The benefits, obstacles and problems of practical BIM implementation, Procedia Engineering, 57, 767-774. https://doi.org/10.1016/j.proeng.2013.04.097

Motawa, I., \& Almarshad, A. (2013). A knowledge-based BIM system for building maintenance. Automation in Construction, 29, 173-182. https://doi.org/10.1016/j.autcon.2012.09.008

Motawa, I., \& Carter, K. (2013). Sustainable BIM-based evaluation of buildings. Procedia-Social and Behavioral Sciences, 74, 419-428. https://doi.org/10.1016/j.sbspro.2013.03.015

Motuzienè, V., Rogoža, A., Lapinskienè, V., \& Vilutienė, T. (2016). Construction solutions for energy efficient singlefamily house based on its life cycle multi-criteria analysis: a case study. Journal of Cleaner Production, 112, 532-541. https://doi.org/10.1016/j.jclepro.2015.08.103

Nath, T., Attarzadeh, M., Tiong, R. L., Chidambaram, C., \& Yu, Z. (2015). Productivity improvement of precast shop drawings generation through BIM-based process re-engineering. Automation in Construction, 54, 54-68. https://doi.org/10.1016/j.autcon.2015.03.014

Niu, S., Pan, W., \& Zhao, Y. (2015). A BIM-GIS integrated webbased visualization system for low energy building design. Procedia Engineering, 121, 2184-2192. https://doi.org/10.1016/j.proeng.2015.09.091

Østergård, T., Jensen, R. L., \& Maagaard, S. E. (2016). Building simulations supporting decision making in early design - A review. Renewable and Sustainable Energy Reviews, 61, 187201. https://doi.org/10.1016/j.rser.2016.03.045

Pautasso, M. (2013). Ten simple rules for writing a literature review. PLoS Computational Biology, 9(7), e1003149. Retrieved from https://doi.org/10.1371/journal.pcbi.1003149

Pavlovskis, M., Antucheviciene, J., \& Migilinskas, D. (2016). Application of MCDM and BIM for evaluation of asset redevelopment solutions. Studies in Informatics and Control, 25(3), 293-302. https://doi.org/10.24846/v25i3y201603

Rolfsen, C. N., \& Merschbrock, C. (2016). Acceptance of construction scheduling visualizations: Bar-charts, Flowlinecharts, Or or Perhaps BIM?. Procedia Engineering, 164, 558566. https://doi.org/10.1016/j.proeng.2016.11.658

Sacks, R., Treckmann, M., \& Rozenfeld, O. (2009). Visualization of work flow to support lean construction. Journal of Construction Engineering and Management, 135(12), 1307-1315. https://doi.org/10.1061/(ASCE)CO.1943-7862.0000102

Saoud, L. A., Omran, J., Hassan, B., Vilutienè, T., \& Kiaulakis, A. (2017). A method to predict change propagation within building information model. Journal of Civil Engineering and Management, 23(6), 836-846. https://doi.org/10.3846/13923730.2017.1323006

Shad, R., Khorrami, M., \& Ghaemi, M. (2017). Developing an Iranian green building assessment tool using decision making methods and geographical information system: Case study in Mashhad city. Renewable and Sustainable Energy Reviews, 67, 324-340. https://doi.org/10.1016/j.rser.2016.09.004

Shadram, F., Johansson, T. D., Lu, W., Schade, J., \& Olofsson, T. (2016). An integrated BIM-based framework for minimizing 
embodied energy during building design. Energy and Buildings, 128, 592-604.

https://doi.org/10.1016/j.enbuild.2016.07.007

Shou, W., Wang, J., Wang, X., \& Chong, H. Y. (2015). A comparative review of building information modelling implementation in building and infrastructure industries. Archives of Computational Methods in Engineering, 22(2), 291-308. https://doi.org/10.1007/s11831-014-9125-9

Singh, M. M., Sawhney, A., \& Borrmann, A. (2015). Modular coordination and BIM: Development of rule based smart building components. Procedia Engineering, 123, 519-527. https://doi.org/10.1016/j.proeng.2015.10.104

Soust-Verdaguer, B., Llatas, C., \& García-Martínez, A. (2016a). Simplification in life cycle assessment of single-family houses: A review of recent developments. Building and Environment, 103, 215-227. https://doi.org/10.1016/j.buildenv.2016.04.014

Soust-Verdaguer, B., Llatas, C., \& García-Martínez, A. (2016b). Critical review of bim-based LCA method to buildings. Energy and Buildings, 136, 110-120.

https://doi.org/10.1016/j.enbuild.2016.12.009

Sun, C., Jiang, S., Skibniewski, M. J., Man, Q., \& Shen, L. (2017). A literature review of the factors limiting the application of BIM in the construction industry. Technological and Economic Development of Economy, 23(5), 764-779. https://doi.org/10.3846/20294913.2015.1087071

Takim, R., Harris, M., \& Nawawi, A. H. (2013). Building Information Modeling (BIM): A new paradigm for quality of life within Architectural, Engineering and Construction (AEC) industry. Procedia-Social and Behavioral Sciences, 101, 23-32. https://doi.org/10.1016/j.sbspro.2013.07.175

Turk, Ž. (2016). Ten questions concerning building information modelling. Building and Environment, 107, 274-284. https://doi.org/10.1016/j.buildenv.2016.08.001

Turskis, Z., Morkunaite, Z., \& Kutut, V. (2017). A hybrid multiple criteria evaluation method of ranking of cultural heritage structures for renovation projects. International Journal of Strategic Property Management, 21(3), 318-329.

https://doi.org/10.3846/1648715X.2017.1325782

Ustinovichius, L., Peckienè, A., \& Popov, V. (2017). A model for spatial planning of site and building using BIM methodology. Journal of Civil Engineering and Management, 23(2), 173-182. https://doi.org/10.3846/13923730.2016.1247748

Valipour, A., Yahaya, N., Md Noor, N., Mardani, A., \& Antuchevičienè, J. (2016). A new hybrid fuzzy cybernetic analytic network process model to identify shared risks in PPP projects. International Journal of Strategic Property Management, 20(4), 409-426. https://doi.org/10.3846/1648715X.2016.1210547

Venugopal, M., Eastman, C. M., \& Teizer, J. (2015). An ontology-based analysis of the industry foundation class schema for building information model exchanges. Advanced Engineering Informatics, 29(4), 940-957.

https://doi.org/10.1016/j.aei.2015.09.006

Volk, R., Stengel, J., \& Schultmann, F. (2014). Building Information Modeling (BIM) for existing buildings - Literature review and future needs. Automation in Construction, 38, 109-127. https://doi.org/10.1016/j.autcon.2013.10.023

Volkov, A., Chelyshkov, P., \& Lysenko, D. (2016). Information management in the application of BIM in construction. The roles and functions of the participants of the construction process. Procedia Engineering, 153, 828-832. https://doi.org/10.1016/j.proeng.2016.08.250

Wang, C., Cho, Y. K., \& Kim, C. (2015). Automatic BIM component extraction from point clouds of existing buildings for sustainability applications. Automation in Construction, 56, 1-13. https://doi.org/10.1016/j.autcon.2015.04.001
Wang, G., \& Song, J. (2016). The Relation of Perceived Benefits and Organizational Supports to User Satisfaction with Building Information Model (BIM). Computers in Human Behavior, 68, 493-500. https://doi.org/10.1016/j.chb.2016.12.002

Wang, K. C., Wang, W. C., Wang, H. H., Hsu, P. Y., Wu, W. H., \& Kung, C. J. (2016). Applying building information modeling to integrate schedule and cost for establishing construction progress curves. Automation in Construction, 72, 397-410. https://doi.org/10.1016/j.autcon.2016.10.005

Won, J., \& Lee, G. (2016). How to tell if a BIM project is successful: A goal-driven approach. Automation in Construction, 69, 34-43. https://doi.org/10.1016/j.autcon.2016.05.022

Won, J., Cheng, J. C., \& Lee, G. (2016). Quantification of construction waste prevented by BIM-based design validation: Case studies in South Korea. Waste Management, 49, 170-180. https://doi.org/10.1016/j.wasman.2015.12.026

Wong, J. K. W., \& Zhou, J. (2015). Enhancing environmental sustainability over building life cycles through green BIM: A review. Automation in Construction, 57, 156-165. https://doi.org/10.1016/j.autcon.2015.06.003

Yalcinkaya, M., \& Singh, V. (2015). Patterns and trends in building information modeling (BIM) research: A latent semantic analysis. Automation in Construction, 59, 68-80. https://doi.org/10.1016/j.autcon.2015.07.012

Yan, H., \& Damian, P. (2008). Benefits and barriers of building information modelling. In $12^{\text {th }}$ International Conference on Computing in Civil and Building Engineering (Vol. 161). Retrieved from http://www.hetnationalbimplatform.nl/files/pages/294_benefits-and-barriers-of-building-information-modelling.pdf

Yeh, C. C. (2017). Using a hybrid model to evaluate development strategies for digital content. Technological and Economic Development of Economy, 23(6), 795-809. https://doi.org/10.3846/20294913.2015.1071293

Zavadskas, E. K., \& Vilutiene, T. (2006). A multiple criteria evaluation of multi-family apartment block's maintenance contractors: I - Model for maintenance contractor evaluation and the determination of its selection criteria. Building and Environment, 41(5), 621-632. https://doi.org/10.1016/j.buildenv.2005.02.019

Zhang, H., Kitchenham, B., \& Pfahl, D. (2008). Reflections on 10 years of software process simulation modeling: a systematic review. In Making globally distributed software development a success story (pp. 345-356). Springer Berlin Heidelberg. https://doi.org/10.1007/978-3-540-79588-9_30

Zhang, L., Wu, X., Zhu, H., \& AbouRizk, S. M. (2017). Perceiving safety risk of buildings adjacent to tunneling excavation: An information fusion approach. Automation in Construction, 73, 88-101. https://doi.org/10.1016/j.autcon.2016.09.003

Zhang, S., Sulankivi, K., Kiviniemi, M., Romo, I., Eastman, C. M., \& Teizer, J. (2015a). BIM-based fall hazard identification and prevention in construction safety planning. Safety Science, 72, 31-45. https://doi.org/10.1016/j.ssci.2014.08.001

Zhang, S., Teizer, J., Lee, J. K., Eastman, C. M., \& Venugopal, M. (2013). Building information modeling (BIM) and safety: Automatic safety checking of construction models and schedules. Automation in Construction, 29, 183-195. https://doi.org/10.1016/j.autcon.2012.05.006

Zhang, S., Teizer, J., Pradhananga, N., \& Eastman, C. M. (2015). Workforce location tracking to model, visualize and analyze workspace requirements in building information models for construction safety planning. Automation in Construction, 60, 74-86. https://doi.org/10.1016/j.autcon.2015.09.009 